\title{
Geology of the Garo deposit, Park County, Colorado
}

By Verl R. Wilmarth

Trace Elements Investigations Report 299

UNITED STATES DEPARTMENT OF THE INTERIOR GEOLOGICAL SURVEY 
UNITED STATES DEPARTMENT OF THE INTERTOR

GEOIOGICAL SURVEY

GEOLOGY OF THE GARO DEPOSIT, PARK COUNTY, COIORADO*

By

Verl R。 Wilmarth

Verl R. Wilmarth

April 1958

Trace Elements Investigations Report 299

This preliminary report is distributed without editorial and technical review for conformity with official standards and nomenclature. It is not for public inspection or quotation.

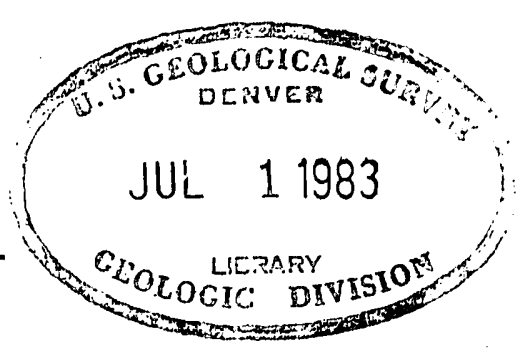

*This report concerns work done on behalf of the Division of Raw Materials of the U. S. Atomic Energy Commission. 
USGS - TEI-299

GEOLOGY AND MINERAIOGY

Distribution

No. of copies

Division of Row Materials, Albuquerque. . . . . . . . . . 1

Division of Raw Materials, Austin .............. 1

Division of Raw Materials, Casper . . . . . . . . . . I 1

Division of Raw'Materials, Denver . . . . . . . . . . . . 1

Division of Raw Materials, Rapid City . . . . . . . . . 1

Division of Rew Materials, Salt Lake City . . . . . . . . I

Division of Raw Materials, Spokane. . . . . . . ..... . 1

Division of Raw Materials, 'Washington . . . . . . . . . 3

Grend Junction Operations Office . . . . . . . . . . . I

Production Evaluation Division, GJOO. . . . . . . . . . 1

Technical Information Service Extension, Oak Ridge. . . . . 6

U. S. Geological Survey:

Foreign Geology Branch, Washington. . . . . . . . .

Fuels Branch, Washington. . . . ........... 1

Geochemistry and Petrology Branch, Washington ....... . 1

Geophysics Branch, Washingtion ... . . . . . . . . . I 1

Mineral Classification Branch, Washington . . . . ... . I

Mineral Deposits Branch, Washington . . . . . . . . . 2

A. L. Brokaw, Grand Junction. . . . . . . . . . . . . 1

N. M. Denson, Denver。................... . . . I

R. I. Griggs, Albuquerque .................. 1

P. E. Hotz, Menlo Park. . . . . . . . . . . . . . 1

W. R. Keefer, Laramie . . . . . . . . . . . . . I 1

E. M. MacKevett, Menlo Park . . . . . . . . . . . I I

I. R. Page, Washington. . . . . . . . . . . . . . . 1

P. K. Sims, Denver. . . . . . . . . . . . . . . 2

Q. D. Singewald, Beltsville . . . . . . . . . . . . I 1

A, E. Weissenborn, Spokane. . . . . . . . . . . . 1

TEPCO, Denver ......................... . . . . . . . . . 2

TEPCO, RPS, Washington, (including master). . . . . . . $\frac{2}{40}$ 
CONTENTS

Page

Abstract ........................ 5

Introduction ..................... 6

Geology ......................... 9

Rock units. ................ 10

Structure ................. 13

Ore deposits................ 16

Localization of ore............ 20

Character of ore ............ 22

Mineralogy ............... . . 26

Paragenesis................. 33

Results of analyses.......... 35

Origin. ................. 36

Suggestions for prospecting .......... 39

Literature cited ............... 40

Unpublished reports. . . . . . . . . . . 40 


\section{ILIUSTRATIONS}

Plate 1. Sketch of polished hand specimens showing

Page mineral relations, Garo deposit, Park County, Colorado. . . . . . . . . . . . . . .

2. Sketch of polished hand specimens showing mineral relations, Garo deposit, Park County, Colorado... . .

Figure 1. Index map of Colorado showing location of Garo deposit . . . . . . . . . . . . . .

2. Geologic map of the Garo deposit near Garo, Park County, Colorado. . . . . . . . . . . In envelope

3. Tectonic map of South Park, Park County, Colorado. . 14

4. Geologic map of pits nos. 1, 2, and 3, Garo deposit, Park County, Colorado . . . . . . . . . . In envelope

5. Exploded isometric diagram showing relation of faults to the ore-bearing sandstone beds, Garo deposit, Park County, Colorado . . .. . . In envelope

6. Sections through diamond drill holes 1, 2, 3, 10, 11, and 12, Garo deposit near Garo, Park County, Colorado............... . . . . . . . envelope

7. Sections through diamond drill holes 4, 5, 6, 7, 8, and 9, Garo deposit near Garo, Park County, Colorado................ . . . . . . envelope TABIE

Table 1. Sample and assay data for Garo deposit, Park County, Colorado. . . . . . . . . . . . . . In envelope 
GEOIOGY OF THE GARO DEPOSIT, PA'RK COUNTY, COLORADO

By Verl R. Wilmarth

$\cdot$ ABSTRACT

The Garo deposit near Garo in the west-central part of Park County, Colo., was mined for radium in 1919 and for uranium, vanadium, and copper in 1951 and 1952.

The ore minerals that constitute the deposit are in 3 complexly faulted sandstone beds of the Maroon formation of Permian age, on the northeast flank of the northwest-trending Garo anticline. Most of the ore that has been mined came from the youngest sandstone bed (bed nio. 1), but some ore has been produced from the oldest sandstone bed (bed no. 3). The ore bodies are small and lenticular and apparently are confined to the more permeable parts of the sandstone bedis adjacent to minor subsidiary faults. Sedimentary structures may have aided in localizing the ore bodies.

Channel samples from the ore bodies in bed no. 1 contain as much as 0.48 percent uranium and 1.37 percent $\mathrm{V}_{2} \mathrm{O}_{5}$, whereas samples from sandstone bed no. 3 contain as much as 0.062 percent uranium and 0.49 percent $\dot{\mathrm{v}}_{2} \mathrm{O}_{5}$. Copper has been produced from sandstone bed no. 1 .

Within the ore bodies, the ore minerals, tyuyamunite, metatyuyamunite, volborthite, camotite, covellite, chalcocite, azurite, and malachite occur in fissure veins and as disseminated grains interstitial to the detrital grains in the sandstone. The dominant gangue minerals are calcite, hematite, limonite, and chalcedony. The original minerals, chalcocite, covellite, pyrite, and posśibly uraninite and montroseite have been 
oxidized and only small remnants of the primary sulfide minerals were observed in the ore. Oxidation of the primary uranium and vanadium minerals resulted in formation of tyuyaminite, metatyuyamunite, volborthite, and camotite and small quantities of uranophane and calciovolborthite.

The Garo deposit is believed to be epigenetic in origin. The ore solutions were derived from a cooling granitic magma that formed the small intrusive mass just east of Garo.

The intersection of faults which cut the rocks of the Maroon formation is a guide in prospecting for uranium in the vicinity of Garo:

\section{INTRODUCTION}

The Garo deposit, known also as the Shirley May mine, is about one mile south of Garo, Park County, Colo., and about 11 miles southeast of Fairplay, the nearest supply center (fig. 1). The mine is at an altitude of about 9,000 feet in the central part of South Park, a broad flat valley between the Front Range on the east and the Mosquito Range on the west. The winters are long and snowfall generally heavy, limiting mining operations to the summer months. Water for mining and domestic purposes can be obtained from the Middle Fork of the South Platte River, 2 miles north of the mine.

According to Fleck (1909, p. 35), the Garo deposit was first prospected in 1903, but no ore was produced at that time. In 1917, the deposit was again prospected; and in 1919 about 40 tons of ore containing as much as one percent uranium was mined (Riley, 1946). The mine was idle from 1919 until 1951, when W. H. Gaddis of Hartsel, Colo., commenced 


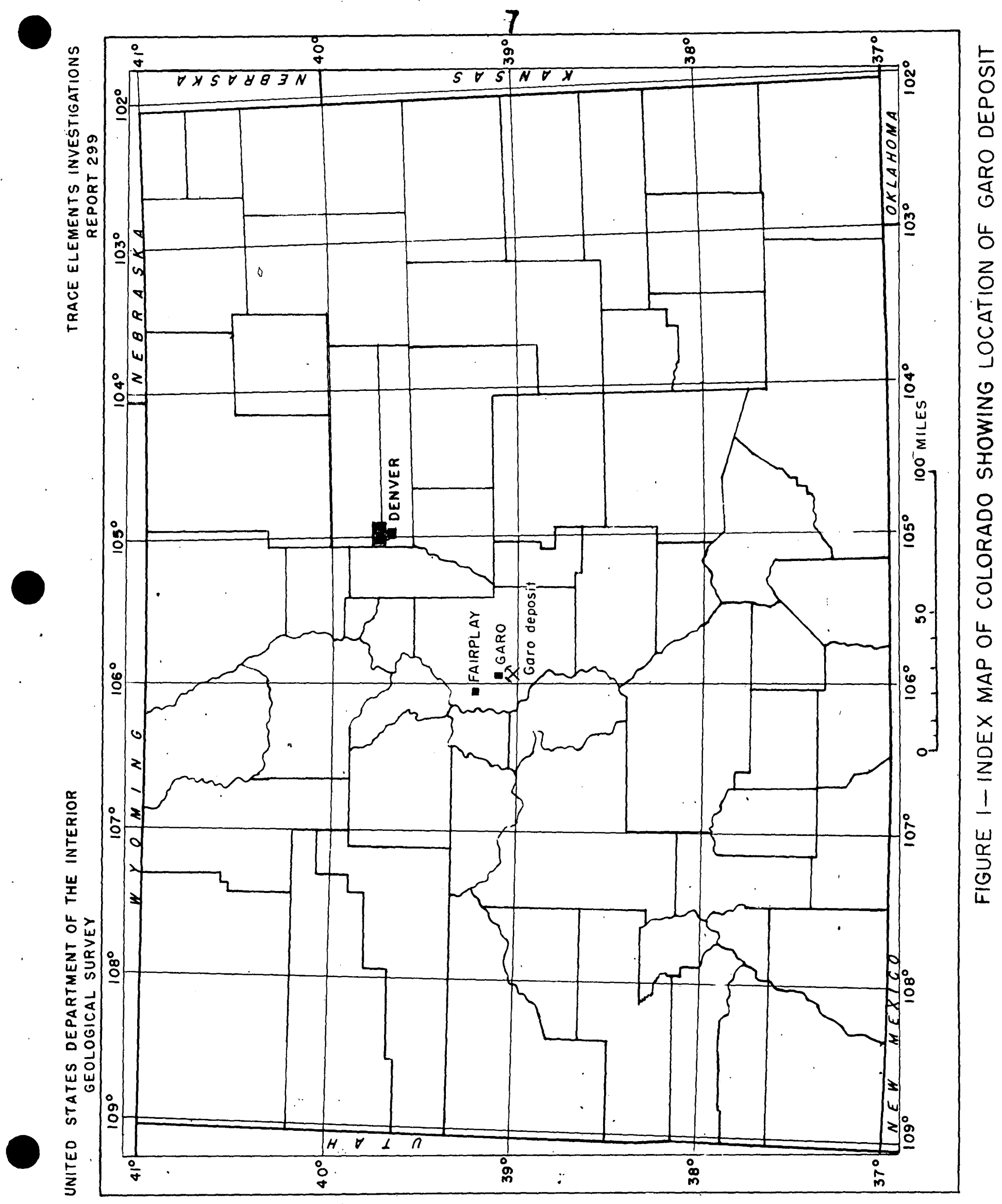


open-pit mining and rehabilitated some of the underground workings. Between July 1, 1951, and July 15, 1952, when mining was again discontinued, ore containing uranium, vanadium, and copper was mined from the open pits.

The Garo deposit was first described by Fleck (1909) who identified volborthite as the principal ore mineral in samples containing as much as 5.5 percent copper and 0.55 percent $\mathrm{V}_{2} \mathrm{O}_{5} \cdot$ Guilotte (1944) briefly described the deposit, and Riley (1946), identified carnotite, volborthite, calciovolborthite, malachite, and azurite in specimens of the dump material. According to stark and others (1949, p. 46), minor quantities of coppervanadium minerals occur in carbon-rich sandstone of the Maroon formation of Permian age near Garo; near Twin Bridges, about 8 miles southwest of Garo, similar sandstones of the Maroon formation contain copper minerals. The Garo deposit was examined briefly and sampled in 1950 by T. P. Anderson (1950), and in 1951 by R. U. King (1951). The first detailed geologic investigation of the ore deposit was made by G. B. Gott (1951), who mapped on a large scale a small area surrounding the deposit.

During June 1952, V. R. Wilmarth and L. R. Page of the Geological Survey and L. E. Smith of the Atomic Energy Commission mapped the geology and topography of approximately one-half square mile surrounding the deposit. This work was undertaken to obtain information on the structure, mode of occurrence, and extent of the ore-bearing formations and to prepare a base map for use in a diamond drilling exploration program. The work was done by the Geological Survey on behalf of the Division of Raw Materials of the U. S. Atomic Energy Commission. The drilling program, 
designed to' explore for new ore bodies at shallow depths and to test the extent of the exposed ore bodies, was carried out by the U. S. Bureau of Mines during July and August 1952. Results of the drilling were described by Wilmarth and Smith (1952).

\section{GEOLOGY}

The Garo deposit is within the part of South Park that was geologically mapped and described by Stark and others (1949). This part of South Park is underlain by red beds of the Maroon formation of Permian age in part covered by glacial and stream deposits of Quaternary age. Near Garo, the Maroon formation is several thousand feet thick (Stark and others, 1949, p. 44-45) and consists predominantly of siltstones, sandstone, and limestones: Within the mine area, series of northwest to northeast high-angle faults have displaced these rocks as much as 1,000 feet horizontally (fig.2).

The ore deposits are in three thick sandstone beds in the Maroon formation that dip steeply northeast. The known ore bodies appear to be lenticular and their close association with faults suggests that' the localization of the ore was controlled in part by faults. The ore bodies consist of uranium, vanadium, and copper minerals irregularly disseminated in the favorable parts of the sandstone beds: Channel samples across the ore bodies contain as much as 0.48 percent uranium, 1.37 percent $\mathrm{V}_{2} \mathrm{O}_{5}$, and 1.34 percent copper (table 1 ). 


\section{Rock units}

The Maroon formation within the mapped area is composed of inter. bedded maroon to white sandstones, siltstones, and shales and light- to dark-gray limestones, Distribution of the mappable lithologic units is shown on figure 2. The sandstones, siltstones, and shales are eroded into low valleys separated by low north-trending ridges of limestones.

The sandstones are fine- to coarse agrained, locally conglomeratic and highly micaceous. They occur in beds from 1 to 30 feet thick. Although crossbedding is well developed in some beds, parallel bedding is dominant. Three sandstone beds in the Maroon formation contain uranium, vanadium, copper minerals, and they have been designated as sandstone beds nos. 1,2 , and 3 .

Sandstone bed no. I is the youngest known ore-bearing lithologic unit and is exposed in pit nos. 1 and 3 , and in prospect pits northwest of pit no. 3 (fig. 2). It averages 9 feet in thickness and is a maroon, fine- to coarse-grained, poorly sorted, calcareous sandstone. In pit no. 1 , bed no. 1 is ore-bearing and is well-cemented, white sandstone, but in pit no. 3, it is dark red-brown to yellow-green to green where ore minerals are abundant.

Sandstone bed no. 2 is stratigraphically 50 feet lower than bed no. $I$ and is only exposed in the prospect pits southwest of pit no. I and west of pit no. 3 (fig. 2). It is 18 to 30 feet thick and is maroon, medium- to coarse-grained, micaceous sandstone that in the upper 3 to 5 feet is a white loosely cemented conglomeratic sandstone containing 
quartz and feldspar grains as much as $1 / 16$ inch across. Yellow-green vanadium-uranium minerals are sparsely distributed in the white conglomeratic sandstone.

Sandstone bed no. 3 is stratigraphically 150 feet lower than bed no. $I$ and is well exposed in pit no. 2 (fig. 2). Bed no. 3 averages 8 feet in thickness. It is a maroon to white fine- to medium-grained, micaceous sandstone that in the lower 2 feet contains a thin lens of white conglomeratic sandstone. In pit no. 2 , bed no. 3 is ore-bearing, and it is a white to yellow-green, friable sandstone.

Shales, siltstones, coarse-grained arkosic sandstones, and fine- to medium-grained sandstone not known to be ore-bearing comprise the bulk of the maroon formation in the mine area. The thin-bedded siltstones, shales, and sandstones range from less than 1 to 22 feet in thickness. They are generally calcareous and maroon to red except where bleached white to gray adjacent to faults and fractures containing calcite or ore minerals. Individual shale and siltsone beds are lenticular and generally are not traceable either along strike or down dip between drill holes. Some of the sandstone beds are more continuous and, from drill-hole data, are traceable throughout most of the mine area. The arkosic sandstones are exposed southeast of the mine and have been cut by drill hole no. 2. These beds are maroon to bright red, very coarse-grained, calcareous massive rocks that contain abundant coarse mica flakes. 
Seven limestone beds were mapped. in the mine area (figs. 2 and 4 ). They range from $I$ to 15 feet in thickness and are light- to darkgray, thin-bedded to massive, fine-grained rocks that locally contain sandstone fragments and chert. A 2 to 7 foot thick limestone bed that is 3 to 15 feet stratigraphically above sandstone bed no. 3 contains abundant radioactive chert. The limestone is dark gray, fine-grained and is well exposed throughout the mapped area. The chert occurs as irregular masses in the limestone and is blue, white, yellow, black and red on fresh surfaces but is white to gray on weathered surfaces. Five samples of variously colored cherts from this bed northwest of fault no.. 2 contain 0.006 to 0.008 percent uranium (fig. 2) and the chemical uranium analyses are nearly the same as is indicated by the measure of total radioactivity. The color of chert is apparently unrelated to radioactivity. According to Gott (1951), cherts from this bed contain in addition to uranium as much as 0.05 percent $\mathrm{V}_{2} \mathrm{O}_{5}$ and 0.04 percent copper.

A chert-bearing limestone bed, 3 to 5 feet thick, was intersected by arill hole nos. 10 and 12 at 20 to 30 feet below the surface. The chert is abnormally radioactive, but the extent of this limestone bed is not known. 
Structure

The Garo deposit is on the northeast flank of the Garo anticline, one of several northwest-trending folds mápped by Stark and others (1949) in the northern part of South Park (fig. 3). The sedimentary rocks in the mapped area have a prevailing strike of N. $60-65^{\circ}$ W., dip $47^{\circ}-73^{\circ} \mathrm{NE}$ and are broken by a series of northwest to northeasttrending high-angle normal and reverse faults (fig. 2) Adjacent to some of the faults, the attitude of the rocks deviates from regional trends.

Faults are the most easily recognized structural feature in the mine, and the more persistent of these have been numbered for reference purposes as fault nos. $1,2,3,4$, and 5. In the mine workings and drill cores, faults are marked by green-white gouge zones, 1 to 4 feet thick, that contain angular to rounded fragments of sedimentary rocks derived from the Maroon formation. In the area northwest of the mine workings, traces of the faults are generally covered by stream and glacial deposits, and the best criterion fon the recognition of faults is the abrupt termination of the sandstone or limestone beds. Faults are also recognized locally, as in pit nos. 1 and 3 and in several drill cores, by change in dip of the beds and by the presence of greenish-white gouge. In addition to the faults shown on figure 2, there are undoubtedly many more strikeslip faults that were not recognized because of their similarity in attitude of the faults and sedimentary rocks. 


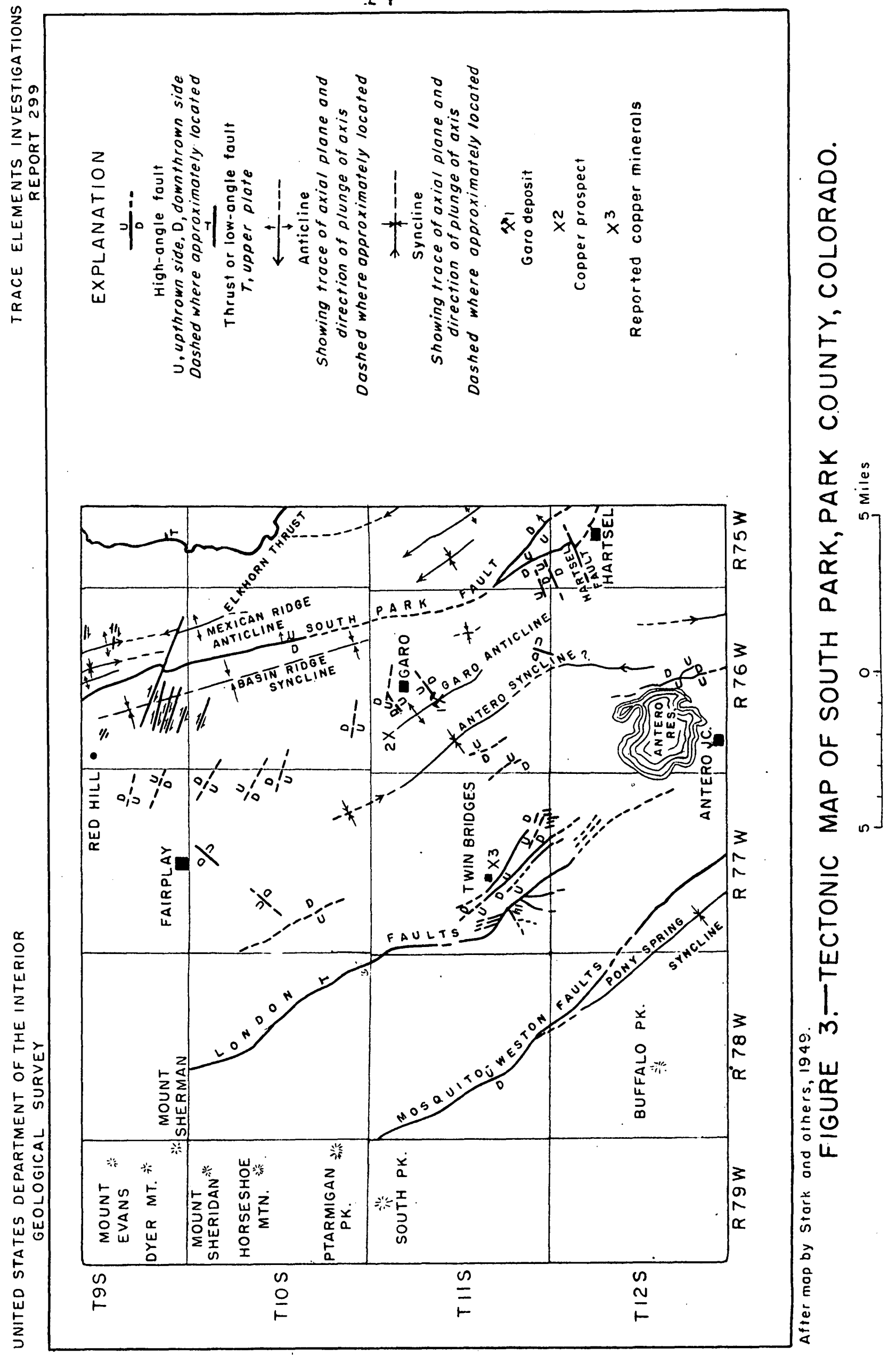


The five principal faults are transverse faults. They strike $\mathbb{N}$. $10^{\circ}$ W. to N. $35^{\circ}$ E., and they dip as much as $88^{\circ} \mathrm{SE}$, as determined from surface and drill hole data. The faults are normal and the apparent relative movement along all except fault no. 3 has been to move the west side of the fault northward. Fault no. 2, the largest fault, has displaced the beds possibly as much as 1,000 feet horizontally and 60 feet vertically. Many steeply dipping normal and reverse subsidiary faults have greatly complicated the structure between fault nos. 2 and 5. Most of these subsidiary faults trend northeast, but some trend northwest parallel to attitude of the sedimentary rocks. They have horizontal displacements of from 5 to 50 feet and probably were formed contemporaneously. w1th the larger. and persistent faults. Most of the faults are believed to have formed prior to deposition of the ore and aided in localization of the uranium, vanadium and copper minerals.

A primary structural feature of the sedimentary rocks that may have been important in localizing the ore deposits is the apparent difference in attitude of the top and bottom of the ore-bearing sandstone beds. As shown in pit no. 3 and pit no. 2 (fig. 4), the dip of the hanging wall of the mineralized sandstone bed is $6^{\circ}$ to $10^{\circ}$ steeper than the footwall. Thus down the dip of the bed, the orebearing sandstone would appear to pinch out; however, in drill hole no. 4, 'sandstone bed no. $I$ is as thick as in pit no. 3. and sandstone bed no. 3. where cut by drill hole nos. 7 and 8 is not decreased in thickness. Thus the variation in dip across the uniformly 
textured sandstone bed is believed to be due to local thinning caused by scouring during sedimentation, resulting in a local constriction of the bed. The ore bodies in pit nos. 2 and 3 appear to lie up dip from such sedimentary strictures (fig. 5).

Except for the small north-plunging fold with an amplitude of 3 feet exposed in pit no. $I_{2}$ the rocks in the mine, area were not extensively folded during formation of the faults. The effect of the minor folds on localization of the ore deposits is believed to have been slight.

\section{Ore deposits}

The ore deposits at the Garo deposit are of the uranium-vanadiumcopper sandstone type though they differ from most deposits of this type in that chalcocite and covellite and their alteration products are locally important constituents of the ore. Most of the ore was produced from sandstone bed no. 1 in pit nos. $I$ and 3, but small quantities of ore were mined a.lso from sandstone bed no. 3 in pit no. 2. There has been no production from sandstone bed no. 2 but 3 potential ore deposits were discovered by diamond drilling in sandstone bed no. 2 between fault nos. 3 and 4. The principal ore minerals are tyryamunite, metatyuyamunite, volborthite, chalcocite, and covellite; they occur as disseminated grains, as grain coatings, and as fracture fillings in sandstone bed nos. 1,2 , and 3 . 
Copper minerals are widely distributed throughout the mineralized sandstone beds, but only a few tons of copper ore has been produced, principally from sandstone bed no. I in pit no. 3. The grade of the ore varies widely. Selected samples of dump material contain as much as 2.39 percent uranium and 4.34 percent $\mathrm{V}_{2} \mathrm{O}_{5}$, but channel samples across the mineralized sandstones contain from 0.001 to 0.48 percent uranjum, and 0.05 to 1.37 percent $\mathrm{V}_{2} \mathrm{O}_{5}$. The copper content of selected ore samples is as much as 1.34 percent, but the average of channel samples from the ore-bearing sandstone is about $0.0 \mathrm{x}$ percent copper. Small quantities of silver, lead, titanium, and zinc are present in the ores (table 1 ).

The ore produced from sandstone bed no. I was mined from pit nos. 1 and 3 in the block of ground between fault nos. 3 and 5 . In pit no. 1 sandstone bed no. I was mined continuously along strike for about 120 feet and down dip for 30 feet. At the widest part, bed no. 1 was mined over a distance of about 30 feet, but the average mining width is about 7 feet. Channel samples of the sandstone from pit no. I (fig. 4) contain 0.001 to 0.035 percent uranium and from 0.09 to 0.19 percent $\mathrm{V}_{2} \mathrm{O}_{5}$ (table 1 ). Although none of these samples is of ore grade (containing more than 0.10 percent uranium), grab samples of ore from a stockpile, collected in 1946 by I. B. Riley, contained 0.32 percent $\mathrm{U}_{3} \mathrm{O}_{8}, 1.38$ percent $\mathrm{V}_{2} \mathrm{O}_{5}$ and 1.90 percent copper (Riley, 1946). The uranium content of samples obtained during mining operations in 1950 and 1951 is considerably higher than that shown by results of analyses of samples collected in 1952 (table 1) and indicates grade of the ore mined prior to 1952 is higher than the average of mineralized rock remaining in pit no. 1. 
Sandstone bed no. 1 in pit no. 1 has been eut by 2 northwesttrending, steeply dipping faults. This faulting may explain the a.bsence of ore minerals in bed no. 1 where cut by drill hole nos. 3 and 11 at depths of 65 and 42 feet down-dip from the bottom of the pit (fig. 6). Samples of the core from bed no. I in these drill holes contain 0.002 percent equivalent uranium (fig.6).

Sandstone bed no. 1 is not exposed between pit nos. 1 and 3 . A sample core from sandstone bed no. I where cut by drill hole no. I contains 0.002 percent equivalent uranium (fig. 6)。 These data suggest that sandstone bed no. 1 is not mineralized between fault no. 4 and pit no. 1. In pit no. 3, the mineralized sandstone has been mined from fault no. 4 northwestward along strike for about 190 feet and down dip for about 15 feet. The extension of the ore body down dip is incompletely known; however, core samples (GA-17-53 and GA-30-53) from bed no. I where cut by drill holes 4 and 9, at depths of 68 and 46 feet down dip from bottom of the pit contain only 0.001 percent equivalent uranium (fig. 7). From these data and convergence of the dips on the foot- and hanging-wall of the sandstone bed (fig. 4), the oremearing part of sandstone appears to pinch out a short distance down dip from bottom of the pit; however, the sandstone bed continues at depth and is 6 to 10 feet thick where cut by the drill holes (fig. 7). Twenty-six channel samples have been cut from bed no. 3 in pit no. 3. Of these, only 4 samples contain more than 0.10 percent uranium; the remaining 22 samples 
contain from 0.001 to 0.096 pereent uranium. Vanadium oxide content of all samples ranges from 0.05 to 1.37 percent and the copper content from 0.12 to 1.34 percent, (table 1 ).

Sandstone bed no. 2 is not mineralized at the surface, but uranium, vanadium, and copper minerals were found in cores from this bed where it was cut by diamond drill holes nos. 1, 4, and 5 (figs. 6 and 7). The top 4 to 5 feet of sandstone bed no. 2 in drill holes 4 and 5 is a white, medium- to coarse-grained, friable rock that contains tyuyamunite, volborthite, and malachite as disseminated grains and on fracture surfaces. Samples from these cores contain 0.003 to 0.018 percent uranium, 0.17 to 0.29 percent $\mathrm{V}_{2} \mathrm{O}_{5}$, and as much as 0.38 percent copper (table 1). In drill hole no. I, volborthite, tyuyamunite, and malachite coat the surface of a quarter of an inch wide fracture in the upper part of the bed, but the sandstone adjacent to the fracture was not mineralized. The extent of the mineralized sandstone cut in the drill holes is not known. Presumably the ore minerals occur in small lenses in the more permeable parts of the sandstone, similar to the ore mined from the surface excavations.

Uranium and vanadium minerals have been mined in sandstone bed no. 3 from the breast of the adit (fig. 4) to the east of pit no. 2. In August 1952, uranium-and vanadium-bearing sandstone formed a zone as much as 3 feet thick and 4 feet long on the hanging wall of the bed, at the east end of the pit. Where bed no. 3 is cut by the diamond drill hole nos. 7 and 8 , no uranium, vanadium, or copper minerals were noted 
in the core and the bed was not abnormally radioactive. Samples of core (GA-27-53 and GA-29-53) contain 0.002 and 0.001 percent equivalent uranium ( $f i g .7$ ). The uranium and vanadium contents of samples (table 1) from pit no. 2 range from 0.001 to 0.062 percent uranium and from 0.05 to 0.49 percent $\mathrm{V}_{2} \mathrm{O}_{5}$. Sample GA-63 contained 0.16 percent copper. At the surface in the small pit about 100 feet northwest of pit no. 2, a channel sample (GA-67-53, table 1) across bed no. 3 contains 0.002 percent equivalent uranium and 0.12 percent $\mathrm{V}_{2} \mathrm{O}_{5}$; no uranium or vanadium minerals were visible. The mineralized part of the sandstone bed is apparently confined to the small area adjacent to a small fault exposed in the pit and appears to pinch out within a short distance down dip from the bottom of the pit and along strike of the bed.

\section{Localization of ore}

The mineralized areas of sandstone bed no. 2 and all the ore deposits that have been mined are between fault nos. 3 and 5 . Specifically, the ore minerals appear to be localized in favorable parts $\odot f$ these sandstone beds where they are cut by subsidiary longitudinal faults (figs. 2 and 5). This relation is well shown in pit no. 3 (fig. 4) where the ore minerals were deposited only in sandstone that is adjacent to and crossed, by a subsidiary longitudinal fault. Similarly, in pit no. 2 ore minerals have been found only in the highly fractured sandstone adjacent to a minor longitudinal fault. The mineralized part of sandstone bed no. 2, as indicated in figure 5, 
appears to be unrelated to longitudinal faults, but the structure of these mineralized areas is incompletely known, and minor faults may be present and may have aided in localizing the ore minerals.

The localization of ore minerals in certain parts of the sandstone beds is due largely to variations in permeability of the host rock. Features of the sandstone that directly affect permeability are composition, texture and structure. Study of thin sections cut from mineralized and unmineralized sandstone has shown that the mineral composition of the detrital grains in both types of sandstone is similar. However, some variation was noted in the carbonate cementing material which with but few exceptions is generally more abundant and coarser grained in the ore-bearing sandstone. Therefore, the original composition of the sandstone was not an important factor in ore deposition.

In the mineralized sandstones, the grain size was an important factor in localizing the ore minerals. Almost always, the coarser-grained parts of the sandstones are mineralized in preference to the finergrained rocks. In those mineralized sandstones that are poorly sorted, the large grains usually were loci for deposition of the ore minerals. From drill hole data the conglomeratic upper part of sandstone bed no. 2 is known to contain ore minerals whereas the fine-grained sandstone in the lower part of the bed is not mineralized.

A primary structural feature observed in the mineralized parts of sandstone bed nos. 1 and 3 is steeper dips on the hanging wall than on the footwall of the bed (fig. 4). This would suggest that the bed would 
pinch out at depth, but from drill hole data the beds are continuous dow dip. The local pinching and swelling of the ore-bearing sandstone coupled with increased permeability from fractures developed during formation of the subsidiary faults may have been important local factors that governed ore deposition.

\section{Character of ore}

Ore at the Garo deposit consists of sandstone impregnated with uranium, vanadium, and copper minerals. It was mined principally for uranium and vanadium, but small quantities of copper ore were also produced. The yellow to yellow-green tyuyamunite, metatyuyamunite, volborthite, and camotite are the most abundant uranium and vanadium minerals, but small quantities of uranophane and calciovolborthite are present locally. The copper ore minerals include chalcocite, covellite, malachite, and azurite. Gangue minerals in the ore are hematite, limonite, calcite, chalcedony, and pyrite; of these calcite is the most abundant.

Mineralogy of the ore pit nos. 1, 2, and 3, though similar, varies widely in the proportions of the ore and gangue minerals present.

In pit no. 1, the ore is characteristically white and contains as much as 25 percent calcite as the cementing material in the sandstone. Tyriyamunite and metatyuyamunite are the common ore minerals and occur as widely disseminated grains that replace the calcite cement and as fracture fillings. Most of the ore mined at the Garo deposit is yellow to yellow green and is generally friable, crudely banded, and contains 
tyuyamunite, metatyuyamunite, volborthite, and camotite as grain coatings, as fissure fillings, as cementing material in the sandstone host rock, and as crystals and crystalline aggregates interstitial to the sand grains. Irregular bands and lenses parallel and subparellel to bedding of host rock are common in the ore and are formed by ore minerals filling interstices of the sandstone. (See pl. IA, IB and pl. 2A.) Hematite is locally abundant in the ore where it occurs along fractures and forms the cement in irregular areas in the sandstone. A selected sample (GA-6) of the yellow-green ore from pit no. 2 contains as much as 0.23 percent uranium and 4.34 percent $\mathrm{V}_{2} \mathrm{O}_{5}$ (table 1 ).

In pit no. 3 copper and iron minerals are locally common constituents of the uranium-vanadium ore. The copper minerals chalcocite, covellite, azurite, and malachite were sufficiently abundant in the ore from the east end of pit no. 3 that small quantities of copper ore were recovered. Specimens of the copper ore show that the copper sulfides occur as narrow fissure veins and as grains disseminated throughout the ore. (See pl.2B, 2C) Most of the chalcocite and covellite is altered to malachite and azurite, but chrysocolla is present in some ore. Some of the ore is banded and consists of a core of altered chalcocite and covellite successively surrounded by rings of tyryamunite, volborthite and malachite or azurite. (See plate 1B.) In other specimens, however, fractures containing tyuyamunite, metatyuyamunite, and volborthite cut areas in which disseminated grains of copper sulfides are in part altered to malachite. The copper content of the ore varies widely 


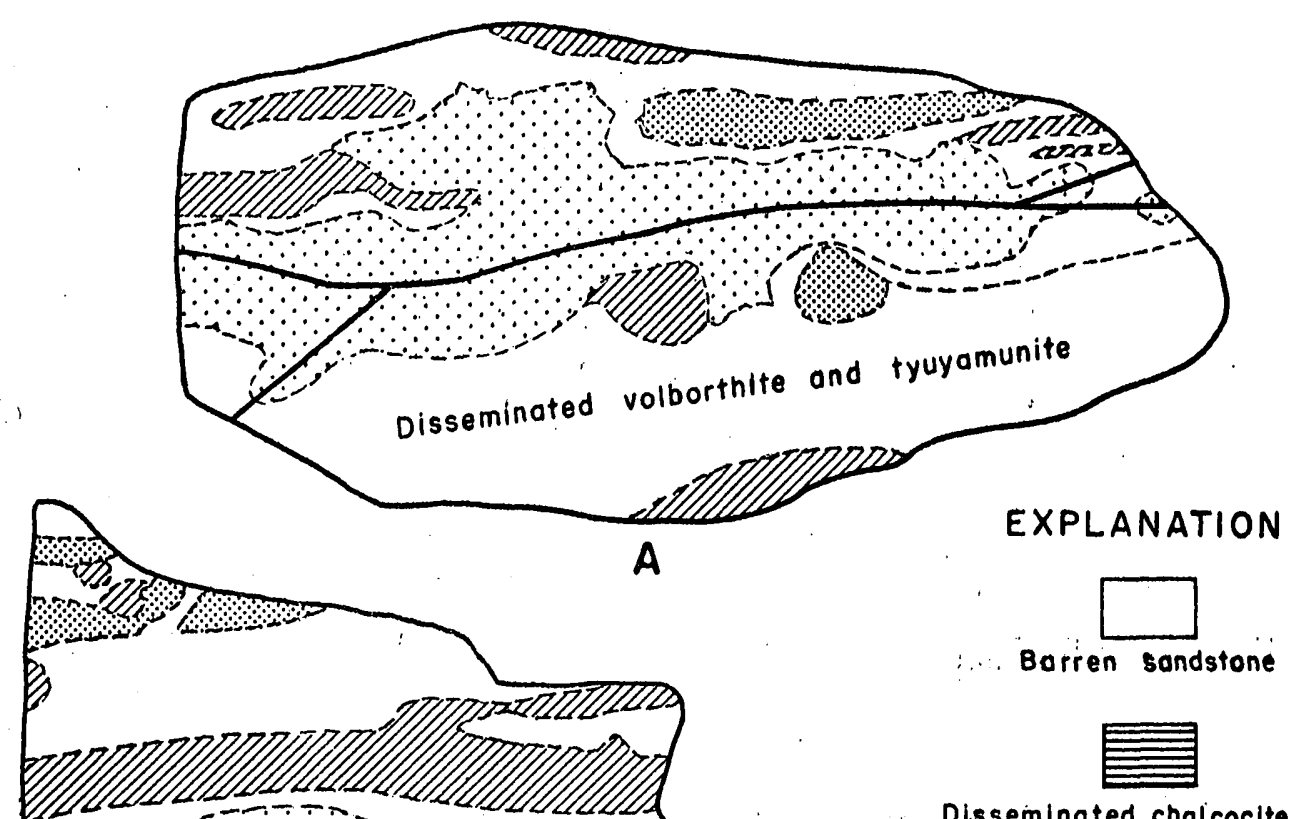
covellite in sondstone

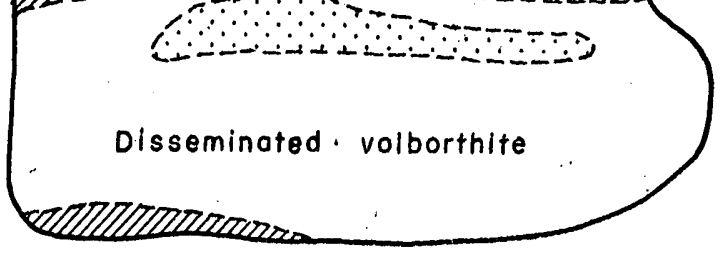

B

Volborthite - rich sandstone

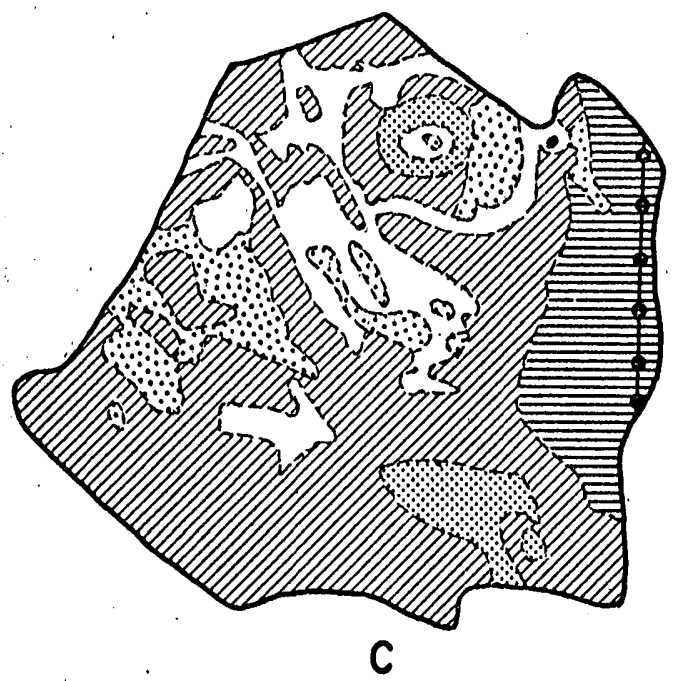

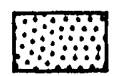

Malachite-rich sandstone

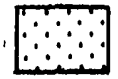

Limonite-rich sandstone

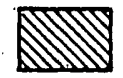

Hematite - rich sandstone
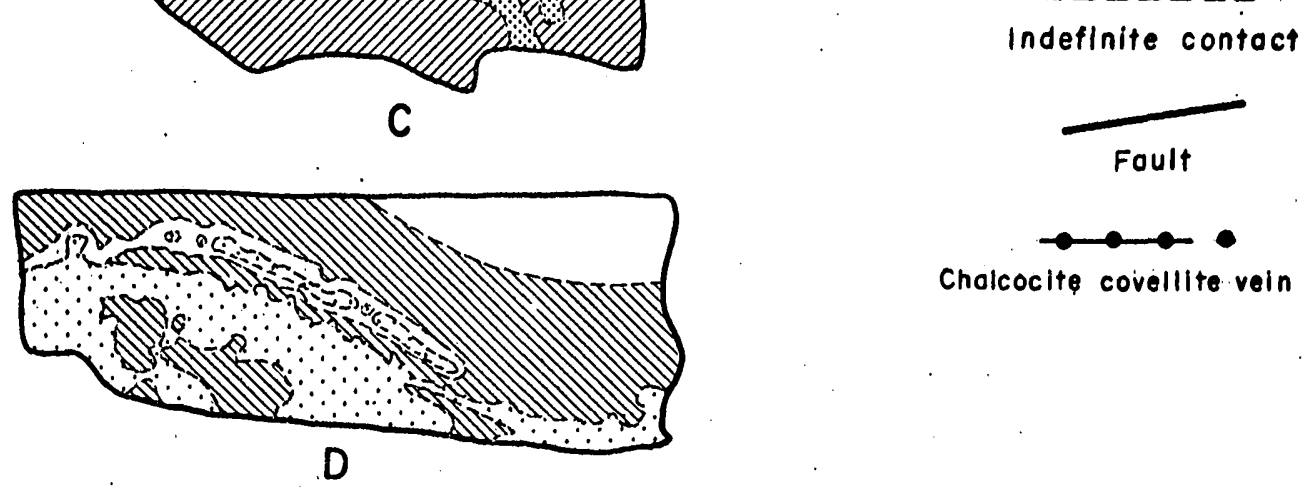

PLATE I- SKETCH OF POLISHED HAND SPECIMENS SHOWING MINERAL' RELATIONS, GARO DEPOSIT, PARK COUNTY, COLORADO. 

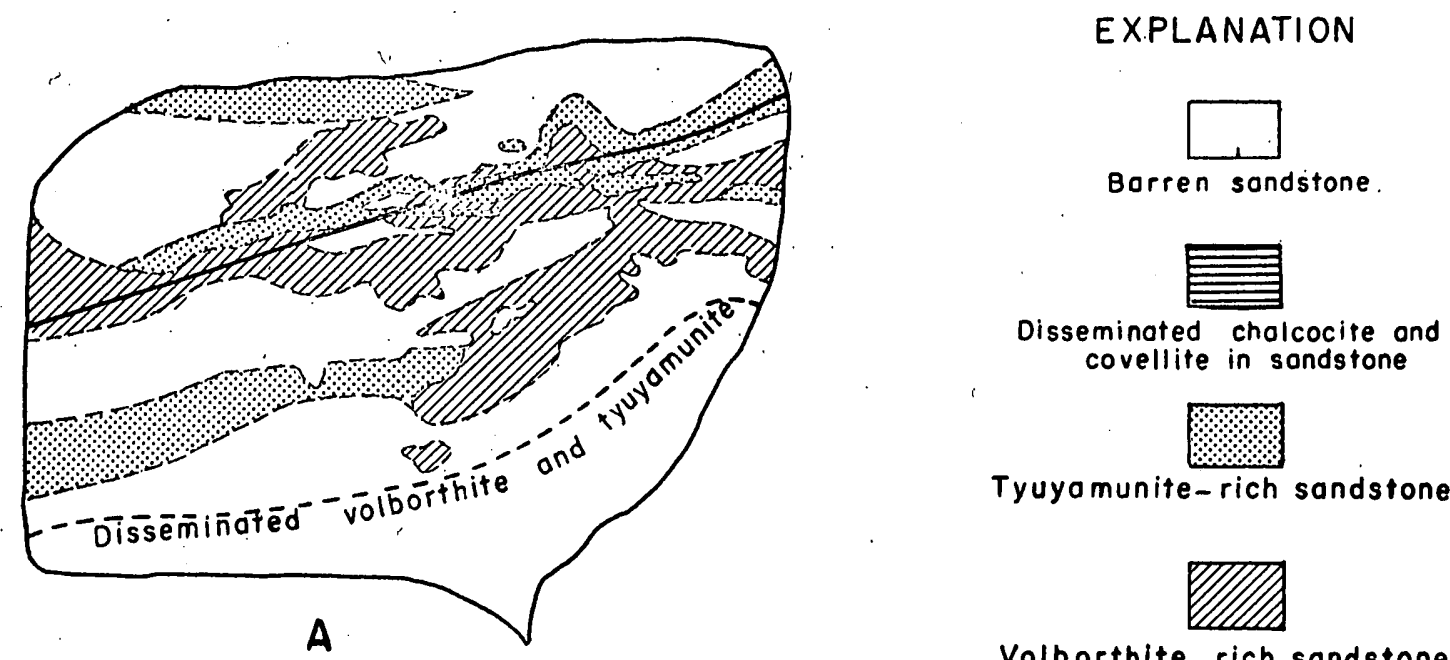

Tyuyamunite-rich sandstone

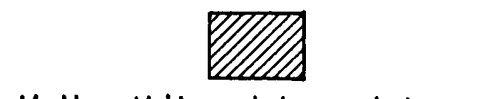

Volborthite-rich sandstone
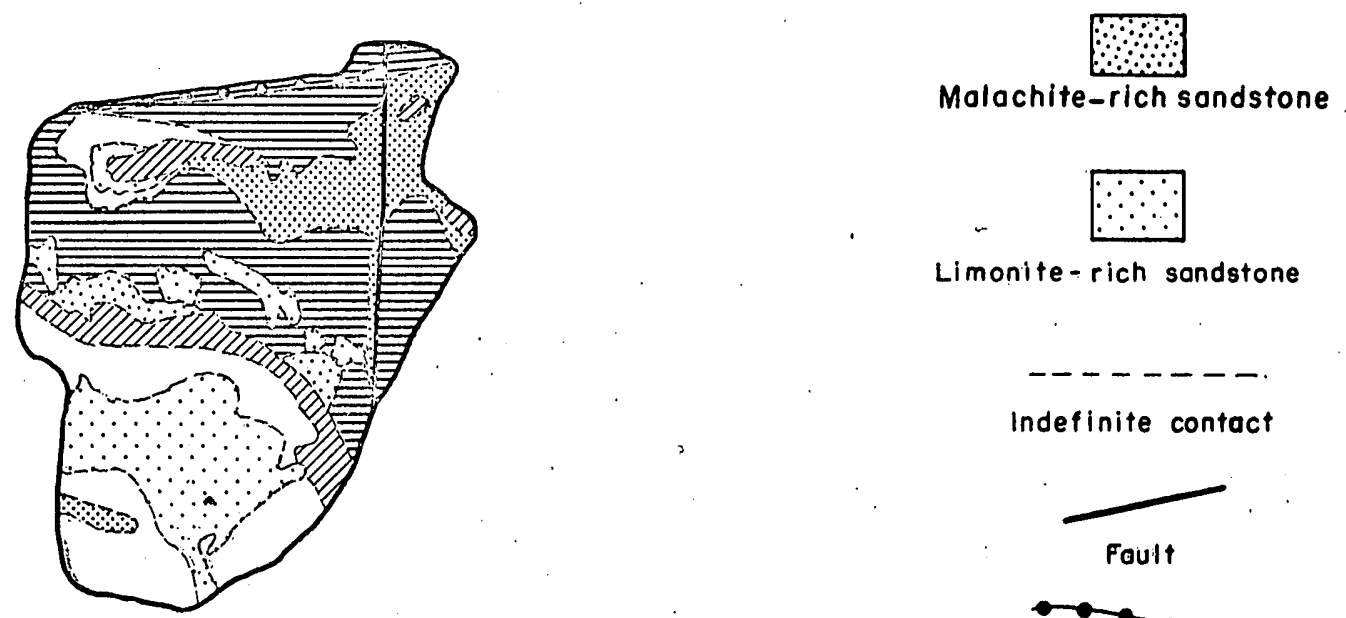

B Indefinite contact

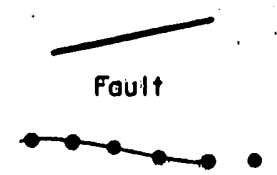

Chalcocite-covellite vein

$x \times x x x x x x x x x$

Calcite vein

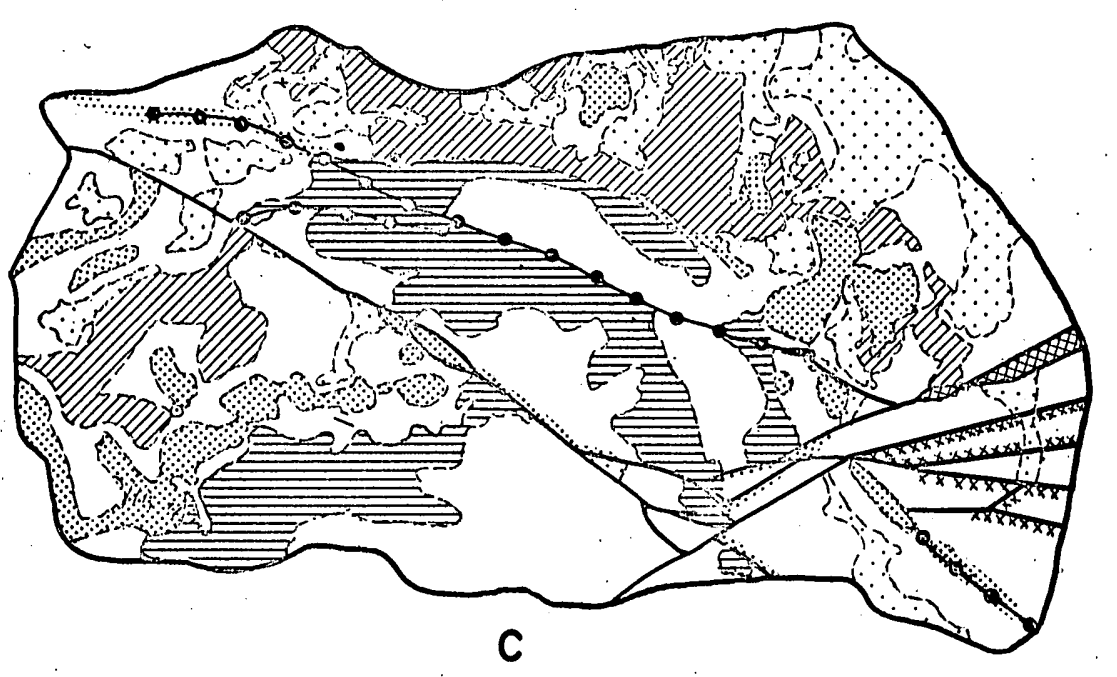

PLATE 2 . - SKETCH OF POLISHED HAND SPECIMENS SHOWING MINERAL RELATIONS, GARO DEPOSIT, PARK COUNTY, COLORADO 
but is as high as 1.34 percent; the average grade is much less (table 1). A selected sample (GA-7) of copper-bearing sandstone from pit no. 3 contains 0.016 percent uranium and 1.21 percent $\mathrm{V}_{2} \mathrm{O}_{5}$ (table 1 ).

The uranium-vanadium ore pit no. 3 , especially the central part of sandstone bed no. 1 , is red-brown, well-cemented, irregularly banded, and contains abundant hematite and limonite. (See plate ${ }^{2}$ r). Ore minerals where observed occur as irregular masses of finely crystalline intergrowths of tyuyamunite, metatyuyamunite, and volborthite widely scattered in the ore. A sample' (GA-5), of the sandstone rich in iron minerals contains 0.002 percent uranium and 0.06 percent $\mathrm{V}_{2} \mathrm{O}_{5}$ (table 1 ).

\section{Mineralogy}

The opaque ore minerals chalcocite and covellite are closely associated with these secondary uranium, vanadium, and copper minerals (named in approximate order of abundance): tyuyamunite, metatyryamunite, volborthite, camotite, malachite, azurite, calciovolbo'rthite, chrysocolla, and uranophane. The gangue minerals are calcite, hematite, limonite, pyrite, and chalcedony. The complex uranium-vanadium minerals were identified by A. B. King and A. J. Gude $3 d$ of the Geological Survey using X-ray diffraction methods. Identification of the opaque minerals and paragenetic relations of the ore and gangue minerals were determined by microscopic study of 65 thin and polished sections of the ore. 
Chalcocite and covellite are the primary copper ore minerals at the Garo deposit. The chalcocite masses are made up of light bluish gray isotropic chalcocite and a light- to dark-blue chalcocite which is for the most part isotropic but may show some faint pale bluish-pink anisotropism. There are all gradations from masses of light gray chalcocite containing few, if any, lath-like crystals of blue chalcocite to lath-like crystals of light gray chalcocite in blue chalcocite. The distinctly blue chalcocite may contain up to 8 percent covellite at room temperature. According to Edwards (1947, p. 74-76), the temperature of formation of blue chalcocite is above $75^{\circ} \mathrm{C}$. Covellite, where observed in polished sections, occurs either as narrow regular plates within, or as rims around, the chalcocite masses.

The chalcocite and covellite are found in narrow fissure veins' but more abundantly as disseminated masses in the sandstone where these minerals replace in part the calcite cement and some of the sand grains. The veins are found only in the highly fractured sandstone adjacent to faults where they range from knife blade to as much as a quarter of an inch in thickness. Within the veins the chalcocite and covellite occur as relict irregular masses as much as $3 \mathrm{~mm}$ across and 1 to $2 \mathrm{~mm}$ wide in irregular veins composed of intermixed malachite, azurite, and secondary uranium-vanadium minerals. Some of the veins are banded; hematite and unreplaced minerals form the core. Malachite forms a narrow zone about the core with the next outer zone composed of hematite-cemented sandstone containing irregular patches and lenses of tyuyamunite-metatyuyamunite-volborthite cemented sandstone. 
Locally replacement of the rounded sand grains along the vein walls results in formation of what has been described by Bastin (1950, p. 42) as atoll structures. The cores of the replaced grains contain relict masses of chalcocite and covellite surrounded by secondary copper, uranium, and vanadium minerals. Hematite containing some tyryamunite forms the outer rim of these structures. The degree of replacement of the sand grains decreases away from the vein until only sparse rounded masses of chalcocite and covellite occur interstitial to the sand grains.

The uranium and vanadium minerals which comprise the ore at the Garo deposit include tyuyamunite, metatyuyamunite, carnotite, volborthite, calciovolborthite, and uranophane. With the exception of uranophane, these ore minerals are uranium-bearing vanadates.

Volborthite is a hydrous copper, calcium, barium vanadate that contains minor quantities of uranium. A selected sample of volborthite obtained from the ore in pit no. 2 contained by spectrographic analysis: XX.O percent each of copper and vanadium, X.O percent calcium, $0 . X$ percent each of barium and uranium and a trace of lead. Although the optical data on the volborthite from this sample are incomplete, $n$ is greater than $1.932,2 \mathrm{~V}$ is moderately large and the birefringence is moderate. Volborthite occurs as disseminated grains, as fracture fillings, and as crystalline aggregates on fracture surfaces in the sandstone. The disseminated volborthite is light to dark green in transmitted light and occurs as finely crystalline aggregates replacing 
the calcite cement. Veins up to $2 \mathrm{~mm}$ wide, consisting dominantly of volborthite, fill fissures in sandstone cemented by volborthite and tyuyamunite and grade into veins consisting of tyuyamunite and malachite. Botryoidal masses of dark-green volborthite occur as coatings on fracture surfaces in sandstone; when these masses are broken, the volborthite is light green. Some of the volborthite coats hematite on fracture surfaces.

Minor quantities of light gray-green lustrous flakes, tentatively identified as calciovolborthite, are closely associated with the volborthite. The calciovolborthite appears to be more abundant in the dark red-brown ore from pit no. 3 .

Tyuyamunite, metatyuyamunite, carnotite, and uranophane are the only uranium minerals known at the Garo deposit. Tyuyamunite, the hydrated calcium uranium vanadate, metatyuyamunite, the dehydrated tyuyamunite, and carnotite, the potassium analogue of tyuyamunite, occur similarly to volborthite. These minerals are closely associated in the ores and though easily identified by $\mathrm{X}$-ray analyses, they are finely crystalline and usually difficult to identify in thin sections.

Tyuyamunite and metatyuyamunite are most abundant and are irregularly distributed throughout the mineralized sandstone beds as a cementing material, as sparse crystals and crystalline aggregates filling interstices, as coatings on fracture surfaces, and in fissure veins. These ore minerals occur as a finely divided crystalline mesh that has replaced the calcite cement in the sandstone and some of the sand grains, 
especially the altered feldspars. Rare crystals as much as $0.05 \mathrm{~mm}$ wide and $0.1 \mathrm{~mm}$ long are present interstitial to the sand grains. In some of the coarse-grained mineralized sandstones coarsely crystalline tyruyamunite occurs as a rind on the larger sand grains. On the more open fractures botryoidal masses up to $3 \mathrm{~mm}$ across of tyuyamunite and metatyuyamunite coat volborthite and hematite.

Tyuyamunite from the Garo deposit has been described by George (1949, p. 164) who gave the following properties: $\alpha=1.675, \beta=1.860$, $Y=1.885$, with $2 \mathrm{~V} 30^{\circ}-45^{\circ} ; \mathrm{Y}=$ greenish yellow, $\mathrm{Z}=$ deeper greenish yellow and $\mathrm{X}=$ colorless. The results of spectrographic analysis of three selected samples of tyuyamunite made by R. G. Havens of the Geological survey are as follows: $\mathrm{XX}$ percent uranium; $\mathrm{X}$ to $\mathrm{XX}$ percent vanaidum; X.O percent each of calcium and silicon; $0 . X$ percent each of barium, aluminum, and strontium; and 0.OX percent copper and iron.

Carnotite and uranophane are present in only minor quantities in the ores. Presence of carnotite, was determined by L. B. Riley (1946). It has not been identified positively by the writer, though probably some of the tyuyamunite and metatyuyamunite contain camotite, especially in those sandstones containing altered' feldspars. Uranophane, calcium uranium silicate, was tentatively identified in thin section of the ore from pit no. 3 where it occurs as finely crystalline radiated aggregates in the chalcedony-cemented sandstone.

Malachite and azurite, the principal alteration products of chalcocite and covellite, fill interstices in the sand'stone where they replace the calcite cement; near the copper-bearing veins, they replace 
some of the sand grains. Some narrow malachite veins cut the uraniumvanadium rich sandstone and represent redistribution of copper by surface waters. Azurite is rarely found in veins but is the cementing material in the sandstone.

Chrysocolla is a rare mineral in the ore and occurs only as a replacement of chalcocite and covellite in the chalcedony-cemented sandstone from pit no. 3.

Calcite is the dominant cementing material in the mineralized, as well as the unmineralized sandstone. It also occurs as veins along faults and joints in the mine area. The calcite cement in the unmineralized sandstone is finely crystalline and contains abundant minute inclusions which gives the calcite a light red color. No evidence was found to indicate replacement of the detrital grains by the calcite cement during lithification. In the mineralized sandstone, the calcite is coarse-grained, commonly clear and replaces in part some of the detrital grains. This calcite may have been introduced by the ore solutions but more likely was the result of solution of the original calcite cement and redeposition in the ore-bearing sandstones. The white- to light-gray vein calcite is coarse-grained and usually forms subhedral crystals, whose long axes are normal to the vein walls. The red- to maroon-sandstones, siltstones, and shales adjacent to the calcite veins are bleached to a light gray. On more open fractures clear euhedral calcite crystals up to $4 \mathrm{~mm}$ long parallel to the fractures walls are coated by crystals of tyuyamunite and volborthite. 
Hematite and limonite are common constituents of the mineralized sandstone from pit no. I, where they occur as interstitial fillings in the sandstone. As is shown in plate $2 \mathrm{D}$, contacts between the reddishbrown limonite- and dark-brown hematite-rich sandstones are sharp and highly irregular; and in some places these sandstones are separated by unmineralized rock. Generally hematite-bearing sandstone surrounds the limonite-rich parts of the sandstone. In thin sections of rock specimens the hematite and limonite have replaced almost wholly the calcite cement and to a lesser extent the sand grains. Semiquantitative spectrographic analyses of selected samples of these sandstones are given in the following table and show there is little variation in the content of the metals present in the rocks. Small masses of subhedral pyrite, largely altered to hematite, are present in some of the copper

Semiquantitative spectrographic analysis

(in percent)

(Analyses by R. G. Havens)

\begin{tabular}{|c|c|c|c|c|c|c|c|c|c|c|c|c|}
\hline & $\mathrm{Fe}$ & $\mathrm{Mn}$ & $\mathrm{Ca}$ & $\mathrm{Mg}$ & $\mathrm{Ag}$ & $\mathrm{Ba}$ & $\mathrm{Cu}$ & $\mathrm{Ga}$ & $P b$ & $\mathrm{~V}$ & Y & $\ln$ \\
\hline $\begin{array}{l}\text { Red-brown limonite- } \\
\text { bearing sandstone }\end{array}$ & . X & $.0 X$ & $\mathrm{X}$ & . $X_{0}$ & $.000 x$ & $.0 \mathrm{X}$ & $.0 X$ & $\operatorname{Tr}$ & $.00 \mathrm{X}$ & $.0 \mathrm{X}$ & $.00 \mathrm{X}$ & $.0 \mathrm{X}$ \\
\hline $\begin{array}{l}\text { Dark-brown hematite- } \\
\text { bearing sandstone }\end{array}$ & $\cdot \mathrm{X}$ & $.0 \mathrm{X}$ & $\mathrm{X}$. &. $\mathrm{X}$ & $.000 \mathrm{X}$ & $.0 \mathrm{X}$ & $.0 \mathrm{X}$ & $\operatorname{Tr}$ & $.00 \mathrm{x}$ & $.0 X$ & $.00 x$ & $.0 X$ \\
\hline
\end{tabular}

sulfide veins. The hematite is locally concentrated at intersections of veins as well as along the vein walls intermixed with secondary uranium, vanadium 
and copper minerals. In addition to the hematite closely associated with the ore minerals, authigenic hematite occurs as very small rounded masses in the calcite cement.

Chalcedony, though not a common gangue mineral in the ore deposit, has replaced some of the calcite cement in the mineralized sandstone from pit no. 3 .

A very fine grained, light-gray, clay mineral is locally abundant in the sandstones adjacent to the fissure veins. It has embayed and replaced some of the detrital grains.

\section{Paragenesis}

The detrital grains which comprise the mineralized sandstone at the Garo deposit were cemented by authigenic calcite prior to orogenic movement which formed the faults and folds in the mine area. Following the faulting and folding, chalcocite, covellite, and minor pyrite were deposited in fractures and as disseminated grains in the sandstones adjacent to the faults. Paragenetic sequence of the sulfide minerals is largely obscured by secondary minerals though it is believed these minerals were deposited contemporaneously. The clay (?) mineral presumably was deposited contemporaneously with the vein minerals.

As seen in polished and thin sections of the ore, some of the hematite as rounded specks is closely associated with the calcite cement and is clearly syngenetic in origin. The hematite which rims and veins the sand grains and locally forms a large part of the vein material was presumably 
derived by the alteration of pyrite. In the sandstone interstices the hematite was formed prior to deposition of the secondary copper and uranium-vanadjum minerals.

Almost all of the chalcocite and covellite masses are veined and replaced by malachite, azurite, and locally chrysocolla. Although this relation is obscured in most of the veins, it is well. shown where the chalcocite occurs as disseminated grains in the sandstones. Following the formation of secondary copper minerals was the deposition of tyuyamunite, metatyuyamunite, carmotite, volborthite, and calciovolborthite. The paragenetic sequence of these minerals is difficult to determine and varies somewhat with the minerals present in the ore. In the more open fractures, botryoidal masses of volborthite are coated by crystals of tyuyamunite. Specimens of the copper-rich ore show, however, that the volborthite-bearing sandstone surrounds the tyuyamunite-rich areas and apparently was deposited later. In thin sections, the euhedral crystals of voliborthite coat the sand grains whereas tyuyamunite and metatyuyamunite fill the interstices between the sand grains and in part replace the volborthite; the reverse of this is also known. In the copper-rich ore where volborthite is apparently more abundant, it replaces the malachite and is in tum veined and replaced by later tyuyamunite. Redistribution of some of the tyuyamunite and volborthite has occurred as shown by these minerals occurring in narrow veins which not only transect chalcocite masses and adjacent areas of malachite but also tyuyamunite and volborthiterich sandstones. In general, deposition of the uranium and vanadium minerals was contemporaneous. 
Small quantities of sericite as long narrow blades cut off tyuyamunite-bearing veins and transect grain boundaries between calcite cement and detrital grains. Sericite was the last mineral formed.

\section{Results of analyses}

Semiquantitative spectrographic analyses (table l) of channel samples from pit nos. 1, 2, and 3, indicate that except for lead, zinc, silver, copper, and titanium, the variation in minor metal content is small. The ores contain a trace of gallium; $0.000 \mathrm{X}$ to $0.00 \mathrm{X}$ percent of cobalt, nickel, vanadium, and yttrium; $0.00 \mathrm{X}$ to $0.0 \mathrm{X}$ percent of strontium, zirconium, and boron; $0.0 \mathrm{X}$ percent manganese; $0 . \mathrm{X}$ percent iron; X.O percent potassium, calcium, sodium, and aluminum and XX. percent silicon. The barium content of the ores averages $0.0 \mathrm{X}$ percent although one sample (GA-49-52) containing O.X percent is also rich in volborthite in which barium is known to replace some of the copper. The small quantity of zirconium present in the ore is found in the zircons which are a minor accessory mineral in the sandstones of the Maroon formation:

The mode of occurrence of the lead, zinc, and titanium is not known as no discrete minerals in which these metals form a component part have been identified in the ore. The copper is undoubtedly contained in the many primary and secondary minerals found in the 
ores. Samples which have a copper content of greater than $0.00 \mathrm{X}$ percent commonly contain detectable quantities of silver, suggesting that silver is associated with the copper minerals.

\section{Origin}

The Garo deposit is believed to be epigenetic in origin; that is, the uranium, vanadium, and copper minerals were introduced into the sandstone beds after deposition, cementation, and faulting of the sedimentary rocks in this area. The source of the metals is not known with certainty; they may have been derived from the wall rocks adjacent to the ore bodies or they may be magmatic in origin.

The extraction of the metals from syngenetic minerals in the sediments that are adjacent to the ore bodies is a possible source. Results of analyses show that copper, uranium, and vanadium are present in the cherts found in the Iimestone beds that are exposed near the mine. Other chert-bearing limestone beds in the Maroon formation in South Park were not studied in detail, but the cherts exposed near Twin Bridges are radioactive though no uranium-vanadium minerals were detected associated with the copper minerals in the adjacent sandstone. Autoradiographs of the chert at the Garo deposit indicated that the uranium is evenly distributed throughout the chert, and it is presumed that the uranium was deposited contemporaneously with the chert. Radioactivity and chemical uranium analyses of the chert are nearly the same, suggesting that little if any of the uranium has been leached from the chert since its deposition. Though cherty limestones are a potential source of uranium, vanadium, and copper, there is no evidence to indicate that these metals were derived from this source. Detrital minerals that 
contain copper, uranium, and vanadium undoubtedly are present in small quantities widely scattered through the sediments of the Maroon formation. Whether these metals were extracted from the detrital grains and reconcentrated in the favorable parts of the sandstone bed at the Garo deposit is not known, though no evidence was obtained to support or deny this process.

The principal evidence for a magmatic source of these metals is the granitic intrusive mass that is exposed only $2 \frac{1}{2}$ miles east-southeast of Garo. According to Stark and others (1949, p. 84), the granitic magma was intruded after the main Laramide oregeny and probably was intruded along the plane of the South Park fault (fig.3).

Briefly, a process which may explain the mineralogic and textural features of the ores at the Garo deposit is as follows: During cooling of the granitic magma, hydrothermal solutions containing the components of the ores, were extruded and channeled out along the the younger and possibly more open northeast-trending faults in the Garo area. The composition of the ore solutions is unknown but can be determined approximately from the paragenesis of the ore minerals. Microscopic study of the ore has shown that chalcocite, covellite, and pyrite were early primary minerais that were deposited in the sandstone. These sulfide minerals are believed to have been deposited from acid hydrothermal solutions which entered the favorable sandstones through the numerous faults that cut the rocks in this area. The formation of minor quantities of clay minerals in the ore and the extensive replacement of the sand grains adjacent to mineralized fractures indicate the ore solutions were chemically active. 
The absence of primary uranium and vanadium minerals, montroseite, uraninite or coffinite in the ore bodies is due largely to their greater instability in oxidizing environments. Remnants of the sulfide minerals were observed in the ore, whereas the primary uranium-vanadium minerals have been completely oxidized and replaced by the secondary uranium, vanadium, and copper minerals. Although the original composition of the ore is not known, the preponderance of secondary uranium and vanadium minerals suggests that primary uranium-vanadium minerals were abundant in the ore. As the acid solutions reacted with the calcite cement, they were neutralized and deposition of the primary uranium and copper minerals ceased.

Subsequently, alteration of the primary ore minerals resulted in the formation of tyuyamunite, metatyuyamunite, volborthite, calciovolborthite, carnotite, uranophane, malachite, azurite, and: chrysocolla. Paragenetic study has shown that malachite and azurite were formed prior to deposition of the secondary uranium and vanadium minerals. This indicates that the copper ions released during oxidation of copper sulfides reacted with carbonate ions to form relatively stable malachite and azurite rather than to form secondary coppervanadates which are stable minerals in the zone of oxidation only if vanadium has a valence of 5 . With progressive oxidation of vanadium to valence of 5, vanadium combined with uranium, of valence 6 , to form tyuyamunite, metatyuyamunite, and the minor quantities of carnotite. Locally volborthite and calciovolborthite were formed contemporaneously with the secondary uranium-vanadates in the sandstone that contained appreciable quantities of copper. 


\section{Suggestions for prospecting}

The outlook for new uranium-vanadium-copper deposits in the vicinity of the mine is difficult to evaluate. South and east of the mine glacial and stream deposits cover much of the bedrock and make prospecting by Geiger or scintillation counter extremely difficult or impossible. Examination of the rocks for several miles northwest of the mine revealed abnormal radioactivity only in the chertiferous limestone beds, though minor quantities of secondary copper minerals were found in prospect pits about 2 miles northwest of the mine. These results indicate that within the area examined the possibility of finding new deposits near the surface is unlikely.

Other areas in South Park, especially near Twin Bridges, that are geologically similar to the Garo deposit are shown on the map by stark and others (1949, pl. 3) and may warrant investigation. Prospecting in these areas could best be carried out by radioactivity surveys by either ground or airborme equipment. 


\section{LITERATURE CITED}

- Bastin, E. J., 1950, Interpretation of ore textures: Geol. Soc. America Mem。 45, $101 \mathrm{p}$.

Edwards, A. B., 1947, Textures of the ore minerals and their significance: Australasian Inst. Min. and Metallurgy, Melbourne $185 \mathrm{p}$. Fleck, Herman, 1909, The vanadium deposits of Garo, Park County, Colorado: Colorado School Mines Quart., v. 3, no. 3, p. 35-36. George, D'Arcy R. 1949, Mineralogy of uranium and thorium bearing minerals: U. S. Atomic Energy Comm. RMO-563. 198 p., issued by U. S. Atomic Energy Comm., Tech. Inf. Service Extension, Oak Ridge, Tenn.

Stark, J. T., and others, 1949, Geology and origin of South Park, Colorado: Geol. Soc. America Mem. 33, 188 p.

\section{UNPUBLISHED REPORTS}

Anderson, T. P., 1950, U. S. Atomic Energy Comm. Reconn. Rept. RR-29. Gott, G. B., 1951, Garo uranium deposit, Park County, Colorado: U. S, Geol. Survey TEM-222, $15 \mathrm{p}$.

Guilotte, G. B., 1944, Report of preliminary field reconnaissance of reported S-37 occurrences in eastem Colorado: Union Mines Development Corp. Rept.

King, R. U., 1951, U. S. Geological Survey Prelim. Reconn. Rept. D-38, March 26, 1951. 
Riley, L. B., 1946, Report on SOM occurrences near Garo, Park County, Colorado: Union Mines Development Corp. Rept.

Wilmarth, V. R., and Smith, L. E., 1952, Results of diamond drilling and geologic investigations of the Shirley May (Garo) uranium deposit, Park County, Colorado: U. S. Geol. Survey TEI-277, 32 p: 
U. S. Geological Survey Library Denver Brannrh 